\title{
Storage and the Use of Peroxydase Enzyme to Detect Germination Capability of Sandoricum koetjape Merr. Seeds- A Neglected Tropical Fruit Species
}

\author{
USEP SOETISNA ", DODY PRIADI, SRI HARTATI, ENNY SUDARMONOWATI \\ Research Centre for Biotechnology, The Indonesian Institute of Sciences (LIPI), Cibinong-Bogor 16911.
}

Received: 17 September 2004. Accepted: 14 October 2004.

\begin{abstract}
Sandoricum koetjape which belongs to the group of mahogany, possesses seeds with sticky white aril, is a neglected local fruit species that might extinct if conservation efforts are not made. Besides preserving the embryos and embryonic axis on different periods of storage $(0,3$, 5,7 days) on a vacuum glass container containing silica gel, the latter organs were also preserved in liquid nitrogen to study the possibility of long-term storage. The water content of the preserved organs was measured in relation to the length of storage and the germination rate. To determine the role of peroxidase in the germination rate of preserved zygotic embryos, the level of peroxidase was measured. Seeds of control and of 3-day storage were mostly germinated at day- 6 . The average rate of germination was reduced to $23.33 \%$ when the seeds were desiccated with silica gel for 7 days which resulted in $27.69 \%$ water content. This germination capability and the length of hypocotyls seem to correlate with peroxidase activity in the seeds. In general, the higher the percentage of germination, the longer the length of hypocotyls, the higher the peroxidase activity, except for seeds desiccated for 7 days. The range of peroxidase activity was $6.81-3856.20$ $\Delta \mathrm{A} / 2 \mathrm{~min} / \mathrm{mg}$. When the seeds were desiccated for 7 days, they still could germinate at day-18 which indicated by a very high peroxidase activity. Peroxidase activity assay could detect the viability within 15 seconds while the TTZ requires 15 minutes. Although the highest percentage of survived embryonic axis after storage in liquid nitrogen was only $23.42 \%$, the results showed that soaking in $10-20 \%$ DMSO for 20 minutes of prerequisite as without DMSO led to no survival. These results offer an alternative procedure to detect the germination ability of seeds at early stage and longer period of preservation which could contribute to future ex situ conservation.
\end{abstract}

(C) 2005 Jurusan Biologi FMIPA UNS Surakarta

Keywords: recalcitrant, seeds, embryos, desiccation, preservation, peroxidase, Sandoricum koetjape.

\section{INTRODUCTION}

Sandoricum which belongs to the family of Meliaceae comprises 5 species, four of which are restricted to western Malesia. The fifth, S. koetjape, is commonly cultivated mainly for its fruit and frequently naturalized from India, Burma (Myanmar) and Indo-China to Thailand, the whole of Malesian region, and tropical Australia and even in the New World Tropics. Timber plantations of S. koetjape have been established in Burma (Myanmar). The wood of this species is used for house construction, furniture, cabinet work, joinery, interior construction, shop fitting, paneling, planking and decking of boats, scantlings, carvings, butcher chopping blocks, packing cases, household implements, and sandals. The wood is also used for the production of veneer and plywood, blackboard, and for pulp and paper. It yields a good-quality charcoal and is used as firewood in Indonesia. It yields a lightweight to medium-weight hardwood with a density of $290-590 \mathrm{~kg} / \mathrm{m}^{3}$ at $15 \%$ moisture content. The texture is moderately fine to slightly coarse and even. In Europe, the timber has been applied for furniture and interior finishing. In Malaysia, the timber is traded in mixed consignments of medium-weight hardwood. Thailand which partly exports to Great Britain, considers this timber is potential (Sosef et al., 1998).

\footnotetext{
- Alamat korespondensi:

Jl. Raya Bogor Km. 46, Cibinong-Bogor 16911

Tel.: +62-21-8754587 Fax.: +62-21-8754588

e-mail: d_priadi2002@yahoo.com
}

This species is a well-known fruit tree, the fruits being eaten fresh or processed into jam and chutney. The fruits of the other Sandoricum are also edible but less palatable. S. koetjape is also an excellent shade tree with ornamental value, is planted as an avenue tree, and is suitable for use in shelter-belts. It has medicinal use as its pounded leaves are sudorific when applied to the skin and are used to make a decoction against diarrhea and fever. The powdered bark is an effective treatment for ringworm, shows anti-cancer activity, and has been used for tanning fishing nets. The roots are employed as an anti-diarrheic, anti-spasmodic, carminative, stomachic and are prescribed as a general tonic after childbirth. Limonoids isolated from the seeds showed insecticidal activity (Sosef et al., 1998).

It is semi-deciduous, small to large trees, up to $45-50 \mathrm{~m}$ tall and occurs scattered in primary or sometimes secondary rain forests, up to $1200 \mathrm{~m}$ altitude. S. koetjape has been reported from lowland dipterocarps forest but also from kerangas on podzolic soils in both perhumid and seasonal climates. It can be propagated by seed, but also by vegetative means like budding, grafting, inarching and marcotting. Seeds however, can not be stored for any length of time. The seed with or without the adhering pulp have $90-95 \%$ germination in $16-31$ days. Various cultivars of this fruit tree exist including the tetraploid ones. Important tree collections are held in the Philippines, Malaysia and Thailand (Sosef et al., 1998).

There are three main categories of seed storage that have been recognized. Roberts (1973) defined orthodox and recalcitrant seeds, as those that survive long term dry storage and those that can not withstand dehydration, 
respectively. More recently, a third category, intermediate, was identified comprising seeds that can withstand dehydration to a certain extent but have reduced longevity. The first one could be further dried to low moisture contents (< 5\%) without losing viability. The second one are characterized by the absence of maturation drying and are shed at moisture contents $>50 \%$ (on a Fresh Weight basis). The so-called intermediate seeds survive drying to moderately low moisture contents (8-10\%) but are often injured by low temperatures (Ellis, 1991).

Zygotic embryos/embryonic axes have been quite widely used in attempts at conserving germplasm of plants with recalcitrant seeds or those with seeds in the intermediate category. Cryopreservation system which is based on the reduction and subsequent detention of the metabolic function, including the cellular division of the explants, is accomplished when materials are brought to the temperature of liquid nitrogen $\left(-196^{\circ} \mathrm{C}\right)$. Successful cryopreservation of plant material should be achievable by the appropriate balance between tissue water content and freezing rate making the use of cryoprotectants a secondary consideration. Thus, flash-drying and very fast freezing rate could be a solution to achieving successful cryopreservation method as suggested by Berjak et al. (1989).

Peroxidase has been implicated in a various physiological processes in plants. Plant peroxidases have been related to several processes such as cell growth, lignin biosynthesis (Gross, 1977), auxin metabolism (Gaspar, 1986), disease resistance, and wound healing (Espelie et al., 1986). Research concerning plant peroxidase activity has been reported in several species such as in mung bean (Chabanet et al., 1993), peanut (Zheng and van Huystee, 1992) and in pedicel of grape (Perez and Gomez, 1998).

The objectives of the study were to investigate possible storage method for seeds and embryonic axes and to determine alternative assay employing peroxidase to detect the viability of seeds of $S$. koetjapi.

\section{MATERIALS AND METHODS}

\section{Source of plant materials}

Seeds were collected from two mature trees grown in the Germplasm Garden of Research Centre for Biotechnology-Indonesian Institute of Sciences in Cibinong, Bogor District, West Java, Indonesia. The trees were originated from seeds which were collected from Serpong, Banten Province. The size of the fruits from where the seeds and embryonic axis were excised was ranging from $5.5 \mathrm{~cm}$ (small fruits) to $8.0 \mathrm{~cm}$ (larger fruits) in diameter in average. The aril was removed from the seeds by scrapping with ash washed and then mixed with fungicide Dithane and followed with natural drying for 1 hour.

\section{Water content determination and germination test}

Fifteen seeds were placed in a container in a desiccator which also contains $200 \mathrm{~g}$ silica gel and kept for either 3, 5 or 7 days. The number of replicates was three. Water content was measured on day 0 and 3-7 days after storage by weighing before and after drying in the oven at $100^{\circ} \mathrm{C}$ for 5 hours. Germination was conducted by placing the seeds on a wetted tissue placed in a germinator at $37^{\circ} \mathrm{C}$. Maintenance was conducted by spraying the tissues containing samples with water every day.
Growth of seeds after desiccation in growing media

Having been maintained in a germinator for one month during the germination test, the desiccated seeds were sown either in the soil or in the sand placed in a plastic tray. They were watered every other day and maintained at room temperature.

\section{Cryopreservation of embryonic axis}

Embryonic axes of S. koetjape were soaked for 20 minutes in either $10 \%$ or $20 \%$ DMSO (dimethyl-sulfoxide) or $6 \%$ sucrose. Prior to freezing, they were placed in cryo tubes and followed with 2 drops of each related cryoprotectant solution. After thawing, the axes were germinated in wetted tissue and watered every day.

\section{Viability test using peroxidase}

Enzyme extraction. Enzyme extraction was carried out by grinding approximately $0.02 \mathrm{~g}$ to $0.1 \mathrm{~g}$ embryonic axis with $1 \mathrm{ml}$ extraction buffer consisting of $25 \mathrm{mM}$ Tris- $\mathrm{HCl} \mathrm{pH}$ 7.5 using a plastic grinder. The homogenate was centrifuged at $10,000 \mathrm{rpm}$ at $4^{\circ} \mathrm{C}$ for 15 minutes. The supernatant was used as crude peroxidase.

Protein determination. Protein content was determined with Bradford solution using the method developed by Grey (1990) using Bovine Serum Albumin as a standard.

Enzyme assay. Total peroxidase activity was estimated colorimetrically according to Campbell and Ellis (1992). The activity was determined by adding $720 \mu \mathrm{l}$ of $50 \mathrm{mM}$ potassium phosphate $\mathrm{pH} 7.0$ to $80 \mu \mathrm{l}$ enzyme extract and $2000 \mu \mathrm{l}$ of $0.5 \%$ guaiacol. The reaction was initiated by adding $2000 \mu \mathrm{l}$ of $0.075 \%$ hydrogen peroxidase followed by rapid inversion. The absorbance of the mixture was monitored at $470 \mathrm{~nm}$ after 2 minutes. Peroxidase activity was expressed as $\Delta \mathrm{A} / 2 \mathrm{~min} / \mathrm{mg}$ protein.

\section{Qualitative viability test}

Tetrazolium test was conducted by applying $23.4 \mathrm{mM}$ TTC solution in $0.05 \mathrm{M}$ phosphate buffer $\mathrm{pH} 7.5$ to both half-cut seeds and embryonic axis. Both germinated and non germinated ones were soaked in the solution for 15 to 60 minutes. Peroxidase solution used was the same as that for quantitative assay. Both materials (half-cut seeds and embryonic axis of germinated and non-germinated) were either soaked in $1 \mathrm{ml}$ solution or given $20 \mu \mathrm{l}$ drop of solution.

\section{RESULTS AND DISCUSSION}

\section{Critical water content and germination pattern}

Water content of seeds before desiccation was $44.63 \%$ which led to $86.67 \%$ germination in average. Desiccating the seeds for 3 days (35.20\% moisture content) did not seem to have an effect on the germination rate as $90 \%$ of seeds still could germinate. Reducing the water content to $31.19 \%$ has caused the germinated rate declined $56.67 \%$ which then dropped to $23.33 \%$ when the water content was reduced to $27.69 \%$ which was achieved by 7 days desiccation. The reduction of the water content not only caused the decline of the germination rate but also the delay in the germination. Without desiccation, seeds would germinate within 6 days while those subjected to desiccation germinated in 10-18 days depending on the water content (Table 1.). Figure 1 . shows the effect of desiccation period on water content and germination rate of S. koetjape seeds. 
Table 1. Effect of desiccation period and water content on germination rate of $S$. koetjape seeds.

\begin{tabular}{cccc}
\hline $\begin{array}{c}\text { Desiccation } \\
\text { period } \\
\text { (days) }\end{array}$ & $\begin{array}{c}\text { Moisture } \\
\text { content } \\
\text { (\%) }\end{array}$ & $\begin{array}{c}\text { Average } \\
\text { germination } \\
\text { rate (\%)* }\end{array}$ & $\begin{array}{c}\text { Peak of } \\
\text { germination } \\
\text { time (days) }\end{array}$ \\
\hline 0 & $44.63 \mathrm{a}$ & $86.67 \mathrm{a}$ & 6 \\
3 & $35.20 \mathrm{ab}$ & $90.00 \mathrm{a}$ & 10 \\
5 & $31.19 \mathrm{ab}$ & $56.67 \mathrm{ab}$ & 14 \\
7 & $27.69 \mathrm{~b}$ & $23.33 \mathrm{~b}$ & 18 \\
\hline
\end{tabular}

Note: * Observation was conducted at day-20. Figures followed with different letters indicate significant different at $1 \%$ based on Duncan Multiple Range Test.

Statistical analysis on the relation between water content and the percentage of germinated seeds showed that 7 days desiccation has reduced the germination rate significantly as the reduction of water content dropped from 44.6 to $27.7 \%$ (Table 1 ).



Figure 1. Effect of desiccation period on water content and germination rate of $S$. koetjape seeds.

The range of water content level which is considered high in order to have high germination rate suggests that this species could be grouped either intermediate or recalcitrant which requires further confirmation through series of research in the future. Critical water content of seeds under this category is varied so preliminary information has to be searched supported with experiments prior to drying or desiccation. In certain recalcitrant seeds, the reduction rate of humidity affected further storage. Azadirachta indica of Thailand provenance could maintain viability over $60 \%$ after 6 weeks storage if the seeds were subjected to sun drying for 2-3 days (Chaisurisri et al., 1986). Seeds of one plant species could behave differently as reported in neem. This plant seed has been designated as being recalcitrant (Ezumah, 1986) but also as orthodox (Tompsett, 1994), while according to Sacande et al. (1997) the seeds had intermediate storage behavior and were cold sensitive. The viable seed showed red color after treated by TTC solution (Figure 2.).

\section{Effect of desiccation and water content on germination in growing media}

The desiccated seeds could still grow and produce roots and shoots after 64-72 days depending on the desiccation treatments and growing media. Most seeds could germinate in the soil regardless desiccation treatments given as the percentage of seeds producing roots was ranging from 89.9 $-100 \%$. Unlike in the soil, those planted in the sand was ranging from $0-100 \%$ depending on desiccation periods
(Table 2.). Although the germination percentage in the sand was lower than in the soil, the number of the roots was higher and they were longer in size (Figure 3.). Sand also resulted shoots to emerge and elongate at 35 days after planting (64-72 days after desiccation and viability test in a germinator). Figure 4 shows the shoot growth of $S$. koetjape seeds which have been desiccated for 5 days at 2 months after sewing in sand placed in a plastic container. Those planted in the soil produced shoot slower as the shoots emerged not earlier than 55 days after planting. This indicates that seeds of $S$. koetjape were still viable for more than 2 months as long as the growing media is appropriate.

The fact that the growth of roots was excessive which tends to repress the growth of shoots, suggest that during germination a growth regulator to stimulate the growth of shoots such as $\mathrm{GA}_{3}$ is required.

Table 2. Effect of desiccation period and growing media on the production of roots and shoots of planted seeds of S. koetjape.

\begin{tabular}{cccccc}
\hline $\begin{array}{c}\text { Desiccation } \\
\text { Period } \\
\text { (days) }\end{array}$ & $\begin{array}{c}\text { Growing } \\
\text { media }\end{array}$ & $\begin{array}{c}\text { Seeds } \\
\text { producing } \\
\text { roots (\%) }\end{array}$ & $\begin{array}{c}\text { Number } \\
\text { of roots } \\
\text { per } \\
\text { seeds* }\end{array}$ & $\begin{array}{c}\text { Seeds } \\
\text { producing } \\
\text { shoots } \\
\text { (\%) }\end{array}$ & $\begin{array}{c}\text { Length } \\
\text { of } \\
\text { shoots } \\
\text { (cm)* }\end{array}$ \\
\hline 0 & Soil & 100 & 5 & 0 & - \\
3 & & 100 & 16.5 & 16.7 & $3.0^{\star *}$ \\
5 & & 89.9 & 11.5 & 14.6 & $1.0^{\star *}$ \\
7 & & 100 & 15 & 0 & $0.5^{\star *}$ \\
\hline 0 & Sand & 100 & 50 & 100 & 3.0 \\
3 & & 50 & 14 & 16.7 & 1.0 \\
5 & & 83.3 & 19 & 33.3 & 4.0 \\
7 & & 0 & - & 0 & - \\
\hline
\end{tabular}

Note: *Observation at day 61 after sewing. ${ }^{*}$ All leaves were not yet opened.

\section{Cryopreservation of embryonic axis}

Embryonic axis which was not treated with DMSO or high sucrose (control) could not survive after storage in liquid nitrogen for 6 days. It seems that the effect of the concentration of DMSO was different to different types of $S$. koetjape. The survival rates were $19.67 \%$ and $23.42 \%$ which seeds were treated with either 10 or $20 \%$ DMSO, respectively. DMSO seems to be more effective than $6 \%$ sucrose as the percentage of survival was slightly higher i.e. $23.42 \%$ and $10 \%$, respectively (Table 3 .).

The results which showed very low survival, suggest that treatments applied were not yet optimum. DMSO alone did not seem to be sufficient to protect embryonic axis to withstand ultra low temperature especially when rapid/direct freezing in liquid nitrogen is applied. Combination of DMSO with other cryoprotectants as has been applied to other plant species might solve the problems. Vitrification or encapsulation dehydration might be one alternative method for preserving embryonic axis of $S$. koetjape. Vitrification solution which employs 30\% glycerol, $15 \%$ ethylene glycol, and $15 \%$ DMSO in liquid medium with $0.4 \mathrm{M}$ sucrose could result in up to $80 \%$ survival of tropical tree species tried after immersion in liquid nitrogen (Sudarmonowati, 2000). Other cryopreservation protocol has been developed mostly for various plant species but mainly temperate species such as Allium cepa (Lakhanpaul et al., 1996). The highest percentage $(62.5 \%)$ of surviving embryos of citrus "Garut" after storage in liquid nitrogen was obtained by dehydrating the naked embryos for 4 hours in laminar air flow and soaked in vitrification solution (a mixture between $0.8 \mathrm{M}$ sucrose and $1.0 \mathrm{M}$ glycerol) for 18 hours (Sudarmonowati et al., 1998). In other plant species such as Ribes nigrum (Benson et al., 1996), encapsulation-dehydration has given a better result than vitrification as it gave a higher survival. 




Figure 2. The assay of viability using TTC (left to right: germinated, not yet germinated but viable, dead).

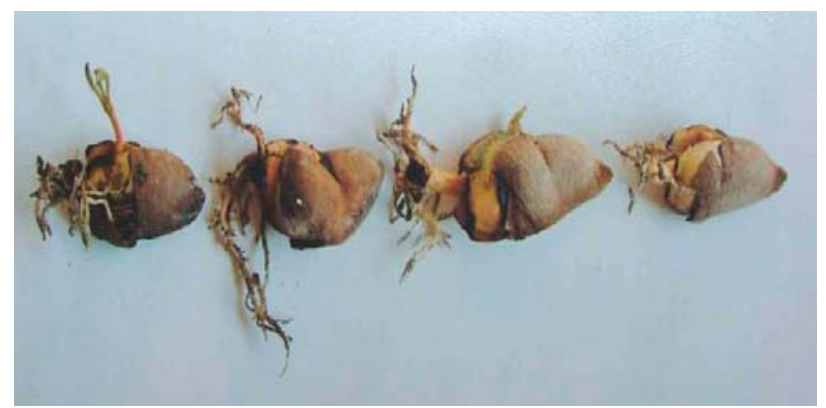

Figure 3. The growth of roots and shoots from seeds of $S$ koetjape which have been desiccated for 0, 3, 5 and 7 days (left to right)

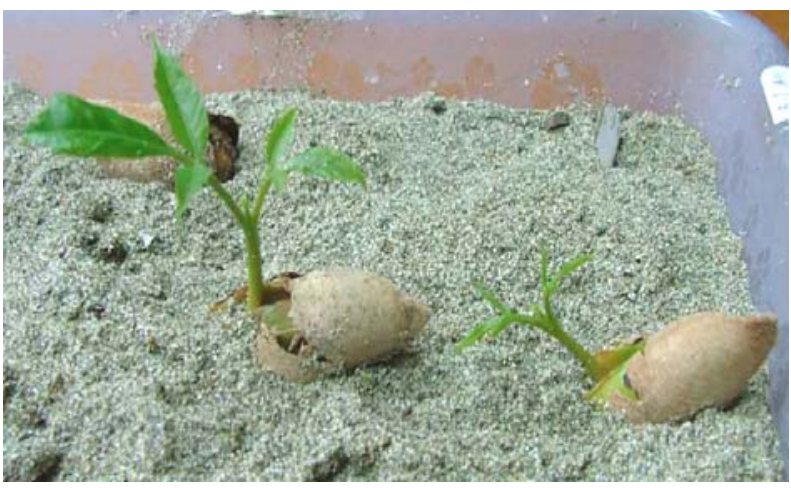

Figure 4. The shoot growth of S. koetjape seeds which have been desiccated for 5 days at 2 months after sewing in sand placed in a plastic container.

On the other hand, embryo axes of "Garut" citrus and longan fruit were more suitable with vitrification technique for preservation. This might be because the composition of vitrification solution tried $(0.8 \mathrm{M}$ sucrose $+0.1 \mathrm{M}$ glicerol + 200 ppm citric acid) might not be sufficient. Other causes might be the high content of phenolic compounds in the zygotic embryos which triggered with the would due to the formation of ice crystal which causes the phenolic compounds accumulated. As different species seems to require different technique, optimum one for each species needs to be developed.

Water content of seeds which embryonic axis was excised was still around $44.63 \%$ which considered still high. Reduction of water content to the optimum one is, therefore, needed which implies that a technique for a more appropriate dehydration needs to be optimized. Storage of the axis at $-196^{\circ} \mathrm{C}$ has reduced the survival; further study is required to optimize the desiccation and freezing procedures. Embryonic axis will still be used as the use of this intact organ has the advantage that if cryopreservation procedures are successful, it should merely be a matter of manipulating post-freezing conditions to produce vigorous plantlets.

\section{Peroxidase for detecting viability of stored seeds}

The level of peroxidase declined in line with the reduction of germination rate, although in certain cases it was deviated. The highest level of peroxidase which was approaching $4000 \mathrm{U}$ was obtained from seeds that have been desiccated for 7 days (Figure 5.).

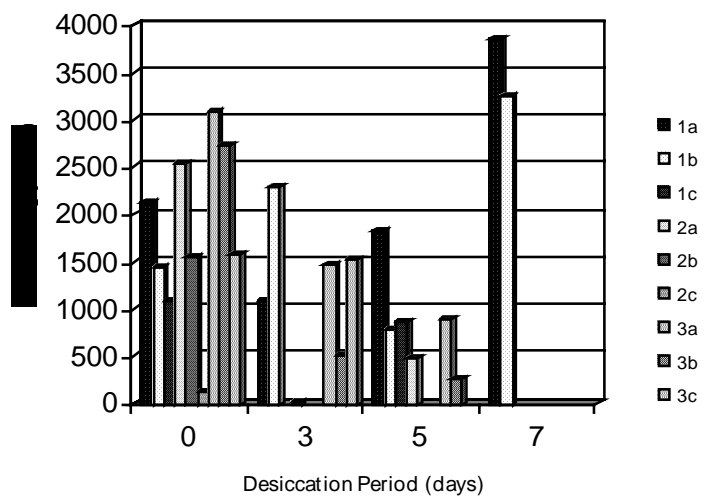

Figure 5. Peroxidase activity of S. koetjape seeds after desiccation up to 7 days.

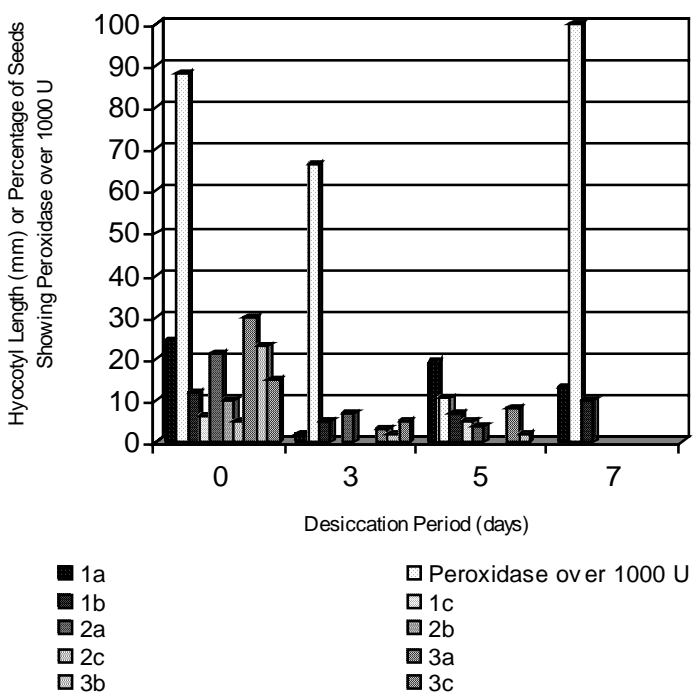

Figure 6. Correlation between desiccation periods, hypocotyls length, and the percentage of germinated seeds of $S$. koetjape showing over $1000 \mathrm{U}$ peroxidase level.

This treatment also led to the highest percentage of seeds containing peroxidase at the level of over $1000 \mathrm{U}$ (Figure 6.). This enzyme also indicates the ability of rooting as the highest content was obtained from organs possessing the longest roots. The higher the hypocotyls of germinated seeds were indicated by higher peroxidase 
level. Peroxidase is considered to be the main enzyme responsible for the catabolism of the phytohormone IAA in higher plants, thereby, the suggestion of its participation in the regulation of plant growth as quoted by Zheng and van Huystee (1992). In terms of IAA catabolism, it can proceed in the absence (IAA oxidase) or presence (IAA peroxidase) of $\mathrm{H}_{2} \mathrm{O}_{2}$. The IAA oxidase and peroxidase catalyzed IAA catabolism was considered as part of auxin regulation in vivo, hence, a part of growth regulation. The correlation between auxin, in this case, IAA with peroxidase content has been proven in peanut as peroxidase content was twofold in hypocotyls cultured on medium containing high IAA (4 mg/l) as compared to control (Zheng and van Huystee, 1992). The fact that the growth of roots was considered excessive in seeds of $S$. koetjape after desiccation which resulted in the repression of shoot emergence indicated that the concentration of IAA is high which related to a high peroxidase level.

This result suggests that not only the viability, the length of hypocotyls of germinated seeds seems to correlate with the level of peroxidase in the seeds. The length of hypocotyls of germinated seeds desiccated for 3 days (35.2\% of water content) was almost uniform while the others varied. In general, the activity of peroxidase was higher in non desiccated seeds and lower when the exposure was longer up to 5 days. In mung bean, the decrease of growth rate of hypocotyls was in parallel with the loss of cell wall extensibility which suggests changes in cell wall structure. The cessation of growth might result from cell wall stiffening processes related to the integration of diphenyl phenolic cross-linked wall polymer subunits into the polysaccharide network which is thought to be catalyzed by specific cell wall peroxidases. It was noted that in mung bean, the development of peroxidase activities in epidermal cell wall just at the onset of growth decrease (Cabhanet et al., 1993). This might explain the increase of peroxidase level when the seeds of $S$. koetjape were desiccated for 7 days.

Giving the peroxidase solution only 2 drops seems to be sufficient for detecting the viability of seeds. The time required using peroxidase for detecting the viability of seeds was much shorter than using TTZ, i.e. 15 seconds versus 15 minutes. The viable and germinated seeds had result much darker solution than the non germinated one (Figure 6.). This technique offers an alternative protocol for detecting the viability of stored tissues as well as other growth function. The role of peroxidase in plant species has been reported such as in Glycine max (Gillikin and Graham, 1991) and in peanut (Zheng and van Huystee, 1992).

\section{CONCLUSIONS}

Drying seeds up to $35.20 \%$ water content could still maintain the germination rate of $S$. koetjape to $90 \%$, although they have been maintained for 2 months. With this condition, the longest storage period will be investigated in the future to confirm whether this water content level is the most optimum one for seed storage. It seems that there was a correlation between the viability of S. koetjape seeds and the level of peroxidase in the seeds. In addition, peroxidase activity might correlate with the growth of this species seeds. Detection of viability with peroxidase assay offers an alternative method to others as it could give faster result. Effort to cryopreserve the seeds or embryonic axis in the future would provide a long-term storage of this recalcitrant species. Various factors affecting the success of this technique, are, therefore, need to be conducted.

\section{ACKNOWLEDGEMENTS}

The authors would like to thank the technical assistance of Ms. Nurchaedar Rahman and Mr. Nanang Taryana. The assistance of Mr. Jitno Rijadi in the documentation of the results was greatly acknowledged.

\section{REFERENCES}

Benson, E.E., B.M. Reed, R.M. Brennan, K.A. Clacher and D.A. Ross. 1996. Use of thermal analysis in the evaluation of cryopreservation protocols for Ribes nigrum L. germplasm. Cryo-Letters 17: 347-362.

Berjak, P., J.M. Farrant, D.J. Mycock and N.W. Pammenter. 1989. Recalcitrant (homoiohydrous) seeds: the enigma of their desiccationsensitivity. Seed Science Technology 18: 297-310.

Campbell, M.M. and B.E. Ellis. 1992. Fungal elicitor-mediated responses in pine cell culture. Planta 186: 409-412.

Chabanet, A., A.M. Catesson, and R. Goldberg. 1993. Peroxidase and phenoloxidase activities in mung bean hypocotyls cell walls. Phytochemistry 33(4): 759-763.

Chaisurisri, K., B. Ponoy, and P. Wasuwanich. 1986. Storage of Azadirachta indica A. Juss seeds. The Embryon 2(1): 19-27.

Ellis, R.H. 1991. The longevity of seeds. Horticulture Science 26: 1119-1125.

Espelie, K.E., V.R. Franceschi, and P.E. Kolattukudy. 1986. Immunocytochemical localization and time course of appearance of an anionic peroxidase associated with tuberization in potato. Archives on Biochemistry and Biophysics 240: 539-545.

Ezumah, B.S. 1986. Germination and storage of neem (Azadirachta indica A. Juss) seeds. Seed Science Technology 14: 593-600.

Gaspar, T., C. Penel, T. Thorpe, and H. Greppin. 1986. Peroxidases 19701980: A Survey of their Biochemical and Physiologic Roles in Higher Plants. Geneva, Switzerland: University of Geneva Press.

Gillikin, J.W. and J.S. Graham. 1991. Purification and developmental analysis of the major anionic peroxidase for the seed coat of Glycine max. Plant Physiology 96: 214-220.

Grey, D. 1990. Enzyme extraction and assessment of enzyme production. In Pollard, J.W. and J.M. Walker (eds.). Methods in Molecular Biology. Vol. 6. New York: Humana Press.

Gross, G.G. 1977. Biosynthesis of lignin and related monomers. Recent Advanced in Phytochemistry 11: 141-184.

Lakhanpaul, S., P.P. Babrekar, K.P.S. Chandel. 1996. Monitoring studies in onion (Allium cepa L.) seeds retrieved from storage at $-20^{\circ} \mathrm{C}$ and $180^{\circ} \mathrm{C}$. Cryo-Letters 17: 219-232.

Perez, F.J. and M. Gomez. 1998. Gibberelic acid stimulation of isoperoxidase from pedicel of grape. Phytochemistry 48(3): 411-414.

Roberts, E.H. 1973. Predicting the storage life of seeds. Seed Science Technology 1: 499-514.

Sacande, M., S.P.C. Groot, F.A. Hoekstra, R. De Castro, and R.J. Bino. 1997. Cell cycle events in developing neem (Azadirachta indica) seeds: are they related to intermediate storage behaviour? Seed Science Research 7: 161-168.

Sosef, M.S.M., L.T. Hong, and A. Prawirohatmodjo (eds.). 1998. Plant Resources of South-East Asia No. 5(3). Timber trees: Lesser-known Timbers. Leiden: Backhuys Publishers.

Sudarmonowati, E, Rosmithayani, and E.S. Mulyaningsih. 1998. In vitro conservation of fruit tree species at $-196^{\circ} \mathrm{C} .2^{\text {nd }}$ Congress of Indonesian Biotechnology Consortium and National Seminar on Biotechnology. Malang, Indonesia, 20-21 September 1998.

Sudarmonowati, E., Rosmithayani, E.S. Mulyaningsih, D. Priadi, and A. Sakai. 2000. Cryopreservation of shoot tips of two leguminous trees (Acacia mangium and Paraserianthes falcataria) using encapsulationdehydration and vitrification. Proceedings of International Workshop on Cryopreservation of Tropical Plant Germplasm. Tsukuba, Japan, 20-23 October, 1998.

Tompsett, P.B. 1994. Capture of genetic resources by collection and storage of seed: a physiological approach In Leakey, R.R.B. and A.C. Newton (eds.). Tropical Trees: the Potential for Domestication and the Rebuilding of Forest Resources. ITE Symposium No. 29, ECTF Symposium No. 1 London, HMSO.

Zheng, X and R.B. van Huystee. 1992. Anionic peroxidase catalysed ascorbic acid and IAA oxidation in the presence of hydrogen peroxide: a defense system against peroxidative stress in peanut plant. Phytochemistry 31 (6): 1895-1898. 